

\title{
THE IMPACT OF COLLECTIVE INVESTMENT SCHEMES ON FINANCIAL INCLUSION IN KENYA
}

\author{
${ }^{1 *}$ Peninah Kimani \\ Postgraduate Student \\ University of Nairobi \\ *Pkimani@british-american.co.ke: \\ $2^{*}$ Dr. Sifunjo Kisaka \\ Lecturer, School of Business \\ University of Nairobi
}

\begin{abstract}
Purpose: The purpose of this study was to determine the impact of collective investment schemes in financial inclusion in Kenya.

Methodology: The research design was descriptive survey study in nature since it focused on all collective investment schemes in Kenya. The target population was collective investment schemes. A sample of 11 collective schemes was selected using random sampling. The second stage of sampling involved the selection of the respondents using a stratified sampling approach. The strata were the various respondents in the schemes. Both qualitative and quantitative data was collected using a questionnaire that consisted of both open ended and close ended questions. Data was analysed using Statistical Package for Social Sciences (SPSS) and results presented in frequency tables to show how the responses for the various questions posed to the respondents. The data was then analysed in terms of descriptive statistics like frequencies, means and percentages.

Results: The findings implied The study concludes that there was low access to financial products in the investment schemes. It is also possible to conclude that the there were several factors that affect financial inclusion in Kenya. These factors include age of the investor, gender, level of education and level of income.

Unique contribution to theory, practice and policy: The study recommended that measures such as target marketing the segments with low access to collective investments and increasing the market budget to investors on financial matters, may be adopted. Such measures would ensure gendered financial inclusion, and inclusion of social economic classes characterized by age, level of income, education and rural urban classes.
\end{abstract}

Keywords: Collective Investment Vehicles. Collective Investment Schemes. Venture Capital Funds. Banking Penetration 
Journal of Poverty, Investment and Development

ISSNxxxx-xxxx (Paper) ISSN xxxx-xxxx (Online)

Vol.1, Issue No.1, pp 54 - 73, 2016

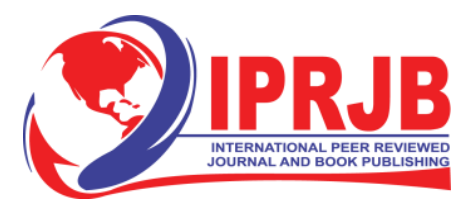

www.iprjb.org

\subsection{INTRODUCTION}

Financial inclusion refers to the process of ensuring access to appropriate financial products and services needed by all sections of the society in general and vulnerable groups such as weaker sections and low income groups in particular, at an affordable cost, in a fair and transparent manner, by mainstream institutional players (Chakrabarty 2011). A financial sector that provides 'accesses to credit for all 'bankable' people and firms, to insurance for all insurable people and firms, to savings and payment services for everyone (United Nations $2006 \mathrm{~b}$ ). Inclusive finance does not require that everyone who is eligible use each of the services, but they should be able to choose to use them if desired.

Collective investments schemes are a crucial segment of the financial sector. They are specialized market players licensed to mobilize savings in financial assets and to enhance access to capital markets by small investors. They were formed with the objective of offering a pool of diversified investment options for all levels of investors in the Kenyan economy. The Capital Markets Act Cap 485 A and also the Capital Markets (Collective Investment Schemes) Regulations, 2001 stipulate that Unit trusts are the small investor's answer to achieving wide investment diversification without the need of prohibitive sums of money. As a market becomes sophisticated and more volatile, unit trusts become safe havens for less, sophisticated and less capitalized, conservative individuals in the market place. They are therefore an avenue of financial inclusion as they are supposed to offer diversification, liquidity, continuous professional management and a broad array of asset investment options to the low income, middle income and large income earners of the economy.

In its development strategy, Vision 2030, Kenya strives to become a regional financial hub with vibrant, efficient and globally competitive financial system to drive savings and investments. This, it is believed, will lead to a high and sustainable, but also broad-based economic growth. There is growing recognition in the current body of knowledge that increasing access to financial services has both private and social benefits. In addition to enhancing efficiency and stability therefore, Vision 2030 identifies the need to increase access to affordable financial services and products for a wider section of Kenyans, particularly poor, low-income households and micro-, small- and medium- scale enterprises (MSMEs). Poor and low income households in informal urban settlements, small and micro-level businesses, rural areas, and women are therefore prioritized in the new vision for financial sector development (Finaccess, 2009).

Surprisingly, despite the growth in formal inclusion, the number of people also using informal services (especially ROSCAs and other community-led groups) has increased from $37.5 \%$ in 2006 to $38.7 \%$ in 2009 . The proportion of financially excluded has decreased from 38.4 to 32.7 , and this is especially apparent in urban areas where financial exclusion was cut in half within a period of barely 3 years (42.9\% in 2006 to 20.9\% in 2009) Financial Sector Inclusion Survey (2010).

\subsection{Statement of the Problem}

Unit trusts are the small investor's answer to achieving wide investment diversification without the need of prohibitive sums of money (Harman, 1987). Collective investments schemes are a crucial segment of the financial sector. They were formed with the objective of offering a pool of diversified investment options for all levels of investors in the Kenyan economy (CMA 
handbook). Kogi(2003) observed that the potential in the Kenyan capital market is yet to be fully utilized as access to the new investment outlets had been limited to the well informed large institutional investors. Maiyo (2007) noted that the unit trust funds had between Kshs. 100,000 to 500,000 being the minimum ceiling an investor could invest in. She concluded that this minimum ceiling is too high for the ordinary Kenyan investor given the low per capita income. She recommended that schemes tailored for the low end of the market should be introduced if the Collective investment schemes are to meet its goals.

Finaccess (2009), did a survey on the financial inclusion in Kenya in 2006 and 2009. They reported a significant jump in the proportion of formally included (26.3\% to $40.5 \%$ ) mainly driven by the advent of mobile money. Another contributor to formal inclusion has been the banking sector up from $18.5 \%$ in 2006 to $22.6 \%$ in 2009. Meanwhile financial exclusion has dropped eight points from $41.3 \%$ to $32.7 \%$ and has virtually been halved in urban areas. Chakrabarty (2011) in his paper on financial inclusion in India indicated that almost half of the country is unbanked, only 55\% of the population has deposit accounts and $9 \%$ have credit accounts with banks.

Finaccess (2009), using a multivariate regression analysis found out that income is one of the strongest predictors of usage of both formal and informal financial services. Higher income earners have higher use of formal and informal financial services than lower income earners while rural Kenyans are less likely to use formal and other informal financial services than urban Kenyans. The study also found out that women are also more likely to be financially excluded than men. Wainaina (2009) concluded that in Kenya, lack of access to financial services is more widespread amongst lower income and rural households and smale-scale enterprises. The expectation of this study is that there will be higher inclusion among the high income earners than among the lower income earners. More inclusion among the urban households than among the rural households and more inclusion of men than women

\subsection{Objectives of the Study}

The objective of the study was to determine the impact of collective investment schemes in financial inclusion in Kenya.

\subsection{LITERATURE REVIEW}

\subsubsection{Financial Inclusion and Development Theory}

Economists hold divergent views regarding the importance of the financial system for economic growth. Walter Bagehot (1873) and John Hicks (1969) argue that it played a crucial role in ushering in industrialization in England by facilitating mobilization of capital. Schumpeter (1912) contended that well-functioning banks spur technological innovation by identifying and funding potential entrepreneurs. Economists like Joan Robinson (1952) opined that, "Where enterprise leads, finance follows", thereby taking a position that economic development creates demand for particular types of financial arrangements and the financial system responds automatically to these demands. Robert Lucas (1988) does not believe that the finance-growth relationship is important and assert that economists "badly overstress" the role of financial factors in economic growth. The literature has categorized the relationship between finance and 
growth into five links; causal relation, demand following, supply leading, negative causal link from finance to growth and interdependence.

The consensus is that finance promotes economic growth but the magnitude of impact differs (Vijayalakshmi and Swamy, 2009). The process of economic growth, especially when it is on high growth trajectory, must strive to encompass participation from all sections of society (Mehrotra, Puhazhendhi, Nair and Sahoo 2009). Lack of access to finance for small farmers and weaker sections of the society has been recognized as a serious threat to economic progress especially in developing countries. Moreover, prolonged and persistent deprivation of banking services to a large segment of the population leads to a decline in investment and has the potential to fuel social tensions causing social exclusion. Finance is at the core of development process. Backed by solid empirical evidence, development practitioners are becoming increasingly convinced that efficient, well-functioning financial systems are crucial in channeling funds to the most productive uses and in allocating risks to those who can best bear them, thus boosting economic growth, improving opportunities and income distribution, and reducing poverty(Worldbank 2008). Conversely, to the extent that access to finance and the available range of services are limited, the benefit of financial development is likely to elude many individuals and enterprises.

\subsubsection{Financial Exclusion/Inclusion Theory}

Financial inclusion or broad access to financial services is an absence of price or non-price barriers in the use of financial services (Worldbank 2008). It is difficult to define and measure because access has many dimensions. Services need to be available when and where desired, and products need to be tailored to specific needs. Services need to be affordable, taking into account the indirect costs incurred by the user, such as having to travel a long distance to a bank branch. Efforts to improve inclusion should also make business sense, translate into profits for the providers of these services and therefore have a lasting effect. According to the worldbank report (2008), financial inclusion does not mean that all households and firms should be able to borrow unlimited amounts at prime lending rates or transmit funds across the world instantaneously for an insignificant amount. Even where the market is competitive and utilizes the best financial technology, prices and interest rates charged and the size of loans and insurance coverage on offer in a market economy will depend on the creditworthiness of the customer. Access essentially refers to the supply of services, whereas use of financial services is determined by demand as well as supply. It is easier to measure the use of financial services since use, can be observed, but use is not always the same as access.

Worldbank (2008), has classified financial access barriers into four main categories; physical barriers, lack of documentation barriers, affordability barriers and lack of appropriate products and services. For Geographic access, branches have been the traditional bank outlet, hence geographic distance to the nearest branch, or the density of branches relative to the population can provide a first crude indication of geographic access or lack of physical barriers to access (Beck, Demirguc-Kunt and Martinez Peria 2007b). Limiting eligibility and documentation requirements is another barrier to access. For example banks in Albania, the Czech Republic, Mozambique, Spain and Sweden demand on average only one document to open a bank account, whereas banks in Tobago, Uganda and Zambia require at least four documents, including an 
identity card or passport, recommendation letter, wage slip and proof of domicile (Worldbank,2008). Given the high degree of informality in many developing countries, only a small proportion of the population can produce these documents.

The issue of cost of financial exclusion maybe conceived from two angles, which are intertwined, first, the exclusion may have cost for individuals in terms of loss of opportunities to grow in the absence of access to finance or credit. Second, from the societal or the national perspective, exclusion may lead to aggregate loss of output or welfare and the country may not realize its growth potential. The more tangible outcomes of financial exclusion include cost and securities issues in managing cashflow and payments, compromised standard of living resulting from lack of access to short-term credit, higher costs associated with using informal credit, increased exposure to unethical, predatory and unregulated providers, vulnerability to uninsured risks, and long-term or extended dependence on welfare as opposed to savings (Chant Link and Associates, 2004)

\subsection{Empirical Literature Review}

The Investment Company Institute (ICI) May (2009) survey report stated that, mutual funds have grown to represent an important part of the U.S. financial system over the past two decades. Between mid-year 1989 and mid-year 2009, assets held in mutual funds have increased from $\$ 899$ billion to $\$ 10.0$ trillion. The number of U.S. households that owned mutual funds rose from 23.2 million to 50.4 million over the same period. As a result, as of mid-year 2009, 43 percent of U.S. households owned mutual funds, representing 87.1 million individual fund shareholders. Furthermore, mutual fund holdings represent a significant component of the savings and investments of many American households, with mutual fund assets now accounting for onefifth of households' financial assets

KPMG (2010) asserts that In India, collective investment schemes are regulated by the Securities and Exchange Board of India (SEBI). SEBI regulates these schemes through specific regulations, guidelines, and circulars issued by it in this respect. Mutual Funds are one form of Collective Investment Vehicles (CIV's) in India. The other forms being Collective Investment Schemes (CIS's) and Venture Capital Funds (VCF's).The beginning of mutual funds in India was laid by the enactment of the Unit Trust of India (UTI) Act in 1963. The objective was to provide investors from the middle and lower income groups with a route to invest in the equity market. It was also meant to encourage savings. UTI brought out its first fund, Unit Scheme (US) 64 in 1964. It called an amount of Rs.246.7 millionS. UTI remained a monopoly in the mutual fund industry till 1987. By then US 64 had grown to Rs.32.69 billion and the overall asset base of UTI was RS.67.38 billion with 25 different schemes (Somasshekar,2008).

In Nigeria, Ibrahim (2005) reported in a research that seeks to evaluate the performance of Collective Investment Schemes in Nigeria between 1990 and 2002 that, the deregulation and liberalization of the financial system following the introduction of the structural adjustment programme by the then military regime in 1986 stimulated a number of financial innovations in line with the changing market conditions. One of such innovations was the commencement of the Mutual Fund or unit trusts schemes in 1990. However, this study did not make a distinction between the growth of the mutual funds (quantity element of financial inclusion) and access to financial services by all classes (quality element of financial inclusion). 
Financial Sector Inclusion Survey (2010) asserted that in 2006, age was a particularly important influence in financial access, and older people were much more likely to use a bank account than younger people. Although the mean age of users had fallen from 39.0 years in 2006 to 37.0 years in 2009, the influence of age was still very strongly positive. In addition, source of income was found to be a key influence in 2006. In particular, 64\% of government employees used a bank account and were five times more likely to be associated with bank use than those whose main income was farming or fishing ( $8 \%$ of whom had a bank account). Those who were in the private sector were twice as likely to be associated with having a bank account, while those employed on domestic chores were ten times less likely and those who were farm employees or who relied on pensions/transfers from others were three times less likely. Level of expenditure was also strongly positively related to use of bank services, as would be expected. Education was also strongly associated with the likelihood of bank use in 2006. In $200613.3 \%$ of women compared to $22.6 \%$ of men used a bank account and being a woman was associated with a significantly lower likelihood of bank access. Since 2006, the proportion using bank accounts has increased in line with the overall average for both genders. However, this has not removed the negative association of being female with bank use $(-2 \%)$.

Finacce (2009), using a multivariate regression analysis found out that income is one of the strongest predictors of usage of both formal and informal financial services. Higher income earners have higher use of formal and informal financial services than lower income earners while rural Kenyans are less likely to use formal and other informal financial services than urban Kenyans. The study also found out that women are also more likely to be financially excluded than men. The expectation of this study is that there will be higher inclusion among the high income earners than among the lower income earners. More inclusion among the urban households than among the rural households and more inclusion of men than women

\subsection{RESEARCH METHODOLOGY}

For this study, a descriptive survey research design was adopted. This study focused on gathering information from teachers, parents and students of Athi River District on the effects of shadow in education in Kenya. There are 29 public secondary schools in the district with 387 teachers and about 10000 students and all the parents. The researcher used purposive sampling technique to select only those schools that have participated in national examinations. A census was used to derive the sample size of the study. 29 schools were included in the sample with one; principal, parent, teacher, and student taken as the respondent from each of the 29 schools. This study used primary data which was collected through use of structured questionnaires. These questionnaires were self-administered for the purposes of collecting data. The study obtained quantitative data only. Quantitative data obtained from the questionnaire was coded for analysis using the Statistical Packages for Social Sciences (SPSS). This analysis helped to generate descriptive statistics. Descriptive statistics aided in analysis of percentages, frequencies and mean of responses.

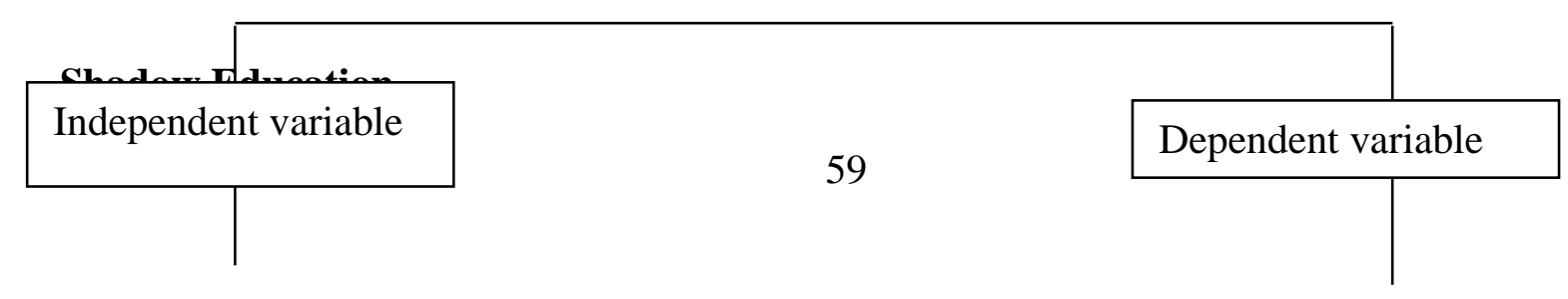




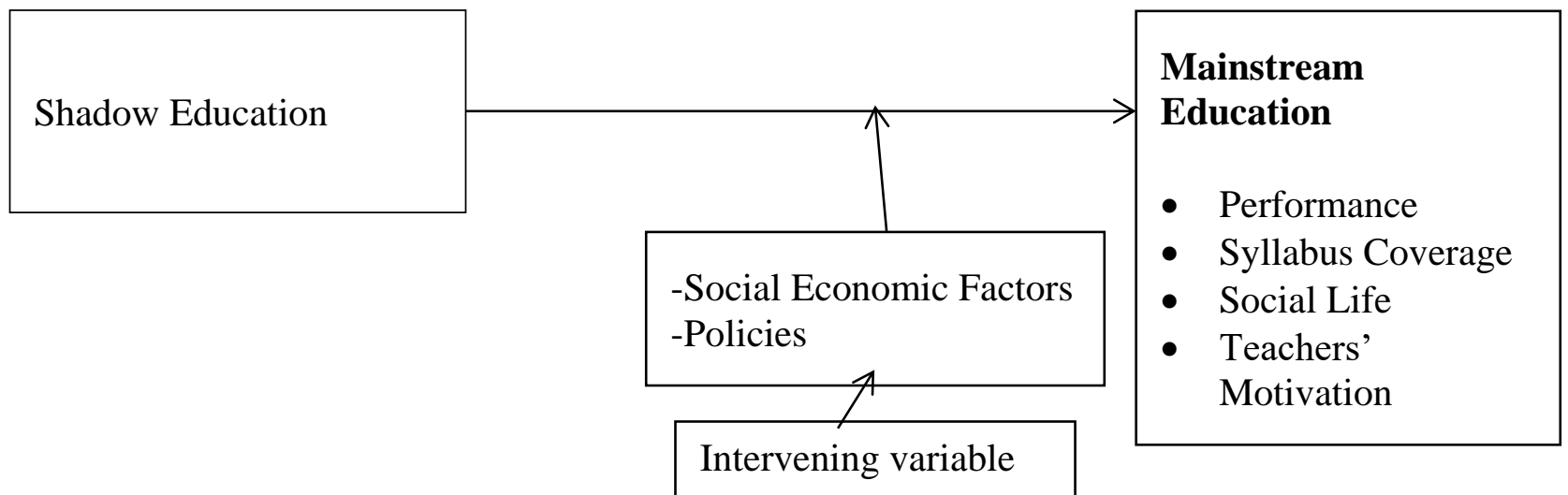

Figure 2.1: Conceptual Framework

\subsection{RESEARCH METHODOLOGY}

The research design was descriptive survey study in nature since it focused on all collective investment schemes in Kenya. The target population was collective investment schemes. A sample of 11 collective schemes was selected using random sampling. The second stage of sampling involved the selection of the respondents using a stratified sampling approach. The strata were the various respondents in the schemes. Both qualitative and quantitative data was collected using a questionnaire that consisted of both open ended and close ended questions. Data was analysed using Statistical Package for Social Sciences (SPSS) and results presented in frequency tables to show how the responses for the various questions posed to the respondents. The data was then analysed in terms of descriptive statistics like frequencies, means and percentages.

\subsection{RESULTS AND DISCUSSIONS}

\subsection{Response Rate}

A total of 68 responses/Questionnaires were received out of a possible 96 Questionnaires. This a response rate of $70 \%$. The unsuccessful response rate was 28 questionnaires (30\%). According to Mugenda and Mugenda (2003), a response rate of more than $50 \%$ is adequate for analysis. Babbie (2004) also asserted that a return rate of $50 \%$ is acceptable for analysis and publishing. He also states that a $60 \%$ return rate is good and a $70 \%$ return rate is very good. The achieved response rate was almost $70 \%$ which implies that the response rate was very good.

\subsection{Demographic characteristics of respondents/Summary Statistics}

\subsubsection{Level of Education}

The respondents were asked to indicate their level of education. Figure 4.3 indicates the findings.

\section{figure1 : Level of Education}




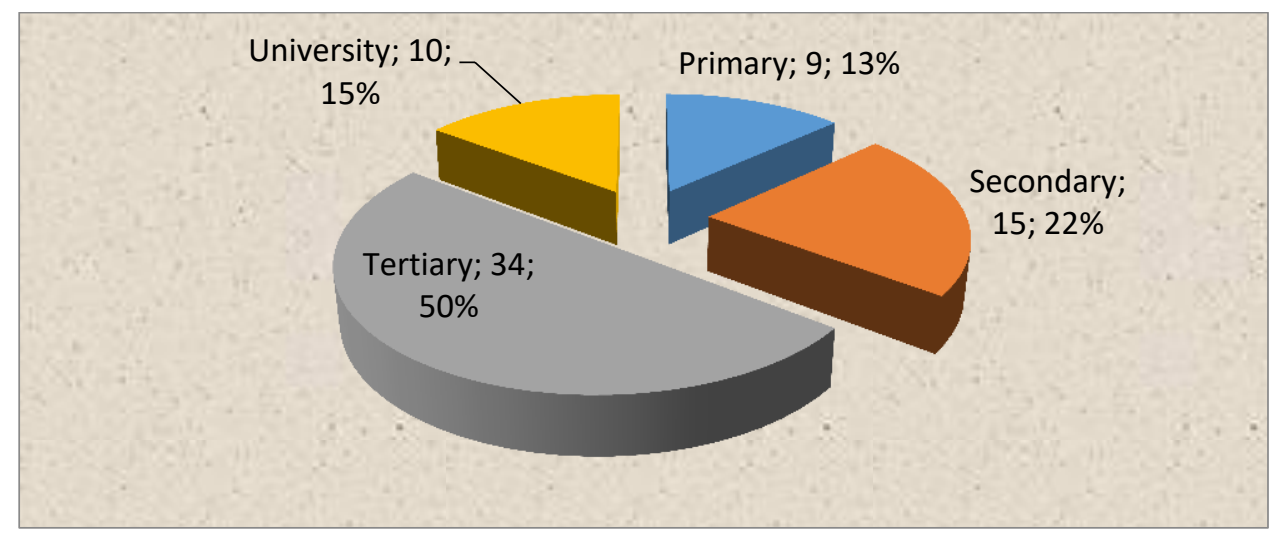

\section{Source: Survey data (2012)}

Results in figure 4.3 reveal that majority $50 \%$ had reached the tertiary level, $22 \%$ had reached secondary level while $15 \%$ were university graduates and $13 \%$ had reached primary level. These results imply that the respondents distributions was more skewed to the tertiary level of education. This may have an implication on the level of financial inclusion.

\subsubsection{Level of Income}

The respondents were asked to indicate their level of income. Figure 4.4 indicates the findings

\section{Figure 2: Level of Income}

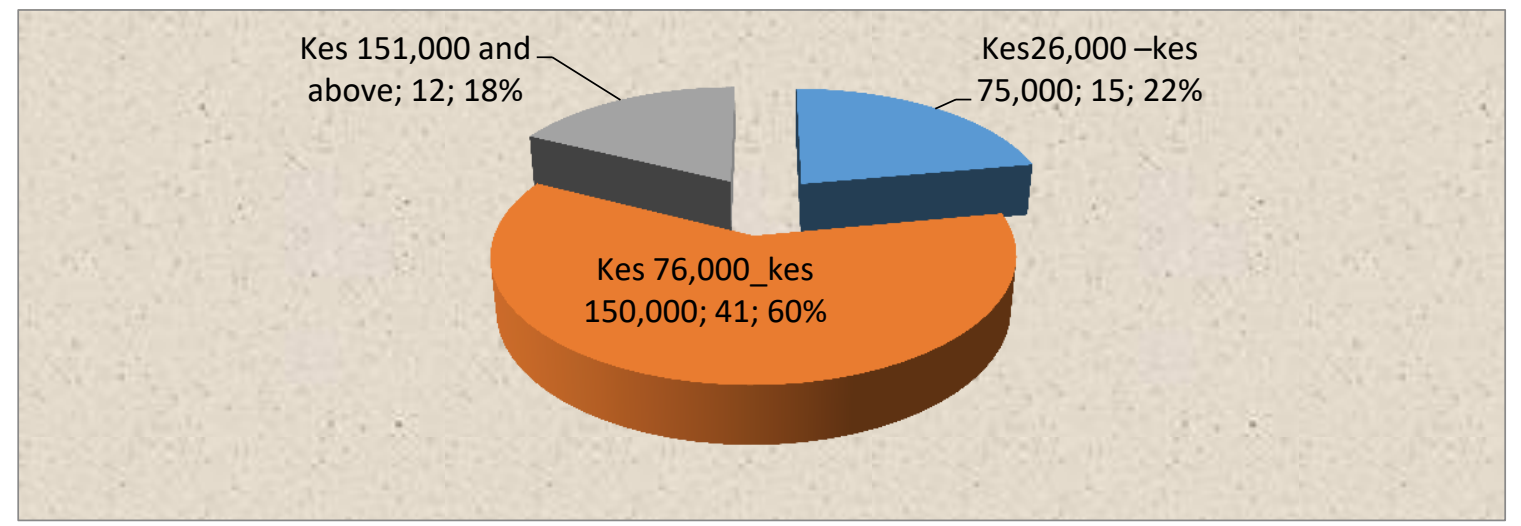

\section{Source: Survey data (2012)}

Results in figure 4.4 reveal that majority $60 \%$ were earning between 76000 and 150,000 shillings, while $22 \%$ respondents were in the category of between 26,000 to 75,000 shillings and $18 \%$ respondents were earning above 150,000 shillings. The findings imply that the level of income is skewed towards towards those earning kes 76,000 to kes 150,000 . This may have a further implication on the level of financial inclusion.

\subsubsection{Distance from nearest collective investment scheme.}

The respondents were asked to indicate the distance from nearest collective investment scheme. The findings are presented in figure 4.5 below. 
Figure 3: Distance

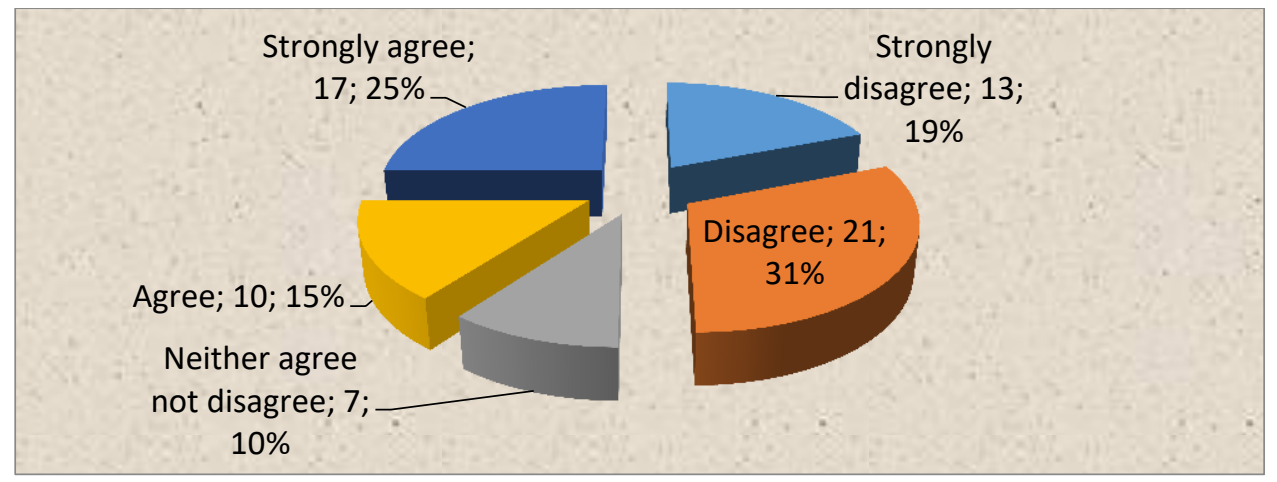

\section{Source: Survey Data (2012)}

Results in figure 4.5 reveal that majority $31 \%$ disagreed and another $19 \%$ strongly disagreed bringing to a total of $50 \%$ of those who disagreed with the statement that Collective Schemes are located far from my residence or my work place. Ten percent neither agreed nor disagreed, while $25 \%$ strongly agreed and 15\% agreed with the statement. The distance from collective investment scheme may have an implication on the level of financial inclusion.

\subsubsection{Financial Inclusion}

The study sought to investigate the level of financial inclusion. The mean scores of the four questions measuring financial inclusion are presented in table 4.1.

\section{Table 1: Measures of financial inclusion}

\begin{tabular}{|l|c|c|c|c|c|}
\hline & $\mathbf{N}$ & Minimum & Maximum & Mean & $\begin{array}{c}\text { Std. } \\
\text { Deviation }\end{array}$ \\
\hline $\begin{array}{l}\text { Since the introduction of collective Investment schemes, } \\
\text { I have increased my investment in one of the } \\
\text { investment options (eg money markets, Capital } \\
\text { Markets) }\end{array}$ & 68 & 1 & 5 & 2.37 & 1.021 \\
\hline $\begin{array}{l}\text { Collective Investment schemes have offered me an } \\
\text { avenue for getting an additional source of income }\end{array}$ & 68 & 1 & 5 & 2.49 & 1.264 \\
\hline $\begin{array}{l}\text { Collective Investment schemes have offered me an } \\
\text { avenue for diversification }\end{array}$ & 68 & 1 & 5 & 2.43 & 1.069 \\
\hline $\begin{array}{l}\text { Collective Investment schemes have offered me } \\
\text { professional management of my wealth }\end{array}$ & 68 & 1 & 5 & 2.21 & 1.333 \\
\hline Total /overall score & & & & $\mathbf{2 . 3 7 5}$ & $\mathbf{0 . 1 2 0 4}$ \\
\hline
\end{tabular}

\section{Source: Survey Data (2012)}

The mean score for the statement that "Since the introduction of collective Investment schemes, I have increased my investment in one of the investment options ( eg money markets, Capital 
Markets" was 2.37. This means score can be rounded to 2. The mean score of 2.37 is represented by "disagree" in the likert scale. This implies a low level of financial inclusion.

The mean score for the statement that "Collective Investment schemes have offered me an avenue for getting an additional source of income" was 2.49. This means score can be rounded to 2. The mean score of 2.49 is represented by "disagree" in the likert scale. This implies a low level of financial inclusion.

The mean score for the statement that "Collective Investment schemes have offered me an avenue for diversification" was 2.43. This means score can be rounded to 2 . The mean score of 2.43 is represented by "disagree" in the likert scale. This implies a low level of financial inclusion.

The mean score for the statement that "Collective Investment schemes have offered me professional management of my wealth" was 2.21 . This means score can be rounded to 2 . The mean score of 2.21 is represented by "disagree" in the likert scale. This implies a low level of financial inclusion.

The overall financial inclusion mean score was 2.375 which implied that the on average the respondents disagreed with the four statements of financial inclusion.

\subsection{Estimated or Empirical Model for Factor affecting Financial Inclusion}

Both correlation and regression analysis were conducted to establish the determinants of financial inclusion. The results of correlation analysis were presented first.

\subsubsection{Regression Analysis}

The study sought to establish the significant determinants of financial inclusion. Regression analysis was conducted to empirically determine the determinants of financial inclusion. The goodness of fit was displayed in table 4.2.

\section{Table 4. 2: Goodness of fit for the model}

\begin{tabular}{|c|c|c|c|c|}
\hline Model & $\mathrm{R}$ & R Square & Adjusted R Square & Std. Error of the Estimate \\
\hline 1 & $.827^{\mathrm{a}}$ & .684 & .659 & .64109 \\
\hline
\end{tabular}

a. Predictors: (Constant)

b. Collective Schemes are located far from my residence or my work place

c. Age

d. Gender

e. Level of Income

f. Level of Education

\section{Source: Survey Data (2012)}

Regression results in table 4.2 indicated the goodness of fit for the regression between determinants and financial inclusion is satisfactory. An R squared of 0.684 indicates that $68.4 \%$ 
of the variance in financial inclusion is explained by the variances in the determinants (independent variables).

Analysis of variance (ANOVA) statistics are presented in table 4.3.

\section{Table 4. 3: Analysis of variance (ANOVA) statistics}

\begin{tabular}{|c|c|c|c|c|c|c|}
\hline \multicolumn{2}{|c|}{ Model } & Sum of Squares & df & Mean Square & $\mathrm{F}$ & Sig. \\
\hline 1 & Regression & 55.205 & 5 & 11.041 & 26.864 & $.000^{\circ}-x-1$ \\
\hline & Residual & 25.482 & 62 & .411 & & \\
\hline & Total & 80.687 & 67 & & & \\
\hline
\end{tabular}

a. Predictors:

i) (Constant),

ii) Collective Schemes are located far from my residence or my work place

iii) Age

iv) Gender

v) Level of Income

vi) Level of Education

b. Dependent Variable: Financial Inclusion

\section{Source: Survey Data (2012)}

Anova results reported an $\mathrm{f}$ statistic of 26.864. The $\mathrm{f}$ statistic is larger than the $\mathrm{f}$ critical. The $\mathrm{p}$ value of 0.000 is less than the conventional critical value of 0.05 . This implies that overall, the model is significant and that the independent variables are good joint predictors of the financial inclusion.

Anova statistics confirm these results since the reported probability was 0.000 , for gender. The reported probability was less than the convectional probability of $0.05(5 \%)$ significance level. The findings are presented in table 4.3.

The regression coefficients were presented in table 4.4

\section{Table 4. 4: Regression Coefficients}

\begin{tabular}{|c|c|c|c|c|c|c|}
\hline \multirow{2}{*}{\multicolumn{2}{|c|}{ Model }} & \multicolumn{2}{|c|}{$\begin{array}{c}\text { Unstandardized } \\
\text { Coefficients } \\
\end{array}$} & \multirow{2}{*}{$\begin{array}{c}\text { Standardized } \\
\text { Coefficients } \\
\text { Beta }\end{array}$} & \multirow[b]{2}{*}{$\mathrm{t}$} & \multirow[b]{2}{*}{ Sig. } \\
\hline & & B & Std. Error & & & \\
\hline \multirow[t]{3}{*}{1} & (Constant) & -2.351 & .935 & & -2.514 & .015 \\
\hline & Gender & .928 & .341 & .403 & 2.723 & .008 \\
\hline & Age & .308 & .391 & .176 & .787 & .434 \\
\hline
\end{tabular}




\begin{tabular}{|l|r|r|r|r|r|}
\hline Level of Education & .683 & .274 & .555 & 2.495 & .015 \\
Level of Income & .503 & .356 & .290 & 1.411 & .163 \\
Collective Schemes are located & -.138 & .082 & -.189 & -1.679 & .098 \\
far from my residence or my & & & & & \\
work place & & & & & \\
\hline
\end{tabular}

a. Dependent Variable: Financial Inclusion

Results in table 4.4 revealed that there is a relationship between gender and financial inclusion is positive and significant $\left(\mathrm{b}_{1}=0.928, \mathrm{p}\right.$ value, 0.008). This was evidenced by a regression coefficient of 0.928 . The associated p value (sig) was 0.008 .

Study findings in table 4.4 revealed that there is a positive but insignificant relationship between age and financial inclusion. This was evidenced by a regression coefficient of 0.308 . The associated $\mathrm{p}$ value (sig) was 0.434 .

Findings in table 4.4 revealed that there is a positive and significant relationship between the level of education and financial inclusion. This was evidenced by a regression coefficient of .683. The associated $\mathrm{p}$ value ( $\mathrm{sig}$ ) was 0.015 .

Results in table 4.4 revealed that there is a positive but insignificant relationship between the level of income and financial inclusion. This was evidenced by a regression coefficient of 0.503 .The associated p value (sig) was 0.163 .

Result in table 4.4 indicates that there is a negative and insignificant relationship between the distance from CIS and financial inclusion. This was evidenced by a regression coefficient of 0.138 . The associated $\mathrm{p}$ value (sig) was 0.098 .

\subsection{Discussion}

The study results indicate that the mean score for the statement that "Since the introduction of collective Investment schemes, I have increased my investment in one of the investment options ( eg money markets, Capital Marets" was 2.37. The mean score for the statement that "Collective Investment schemes have offered me an avenue for getting an additional source of income" was 2.49. The mean score for the statement that "Collective Investment schemes have offered me an avenue for diversification" was 2.43. The mean score for the statement that "Collective Investment schemes have offered me professional management of my wealth" was 2.21. The overall financial inclusion mean score was 2.375 which implied that the on average the respondents disagreed with the four statements of financial inclusion. This further implied that collective investments schemes have not succeeded in bringing about financial inclusion. The findings contrast with those in Finaccess (2009) who reported a significant jump in the proportion of formally included (26.3\% to $40.5 \%)$ mainly driven by the advent of mobile money. The findings also contrast with those in Kagunga (2010) who observed that that there has been a dramatic increase in the number of individuals who want to invest in the securities offered in the Nairobi Stock exchange. The findings agree with those in Chakrabarty (2011) in his paper on financial inclusion in India which indicated that almost half of the country is unbanked, only $55 \%$ of the population has deposit accounts and $9 \%$ have credit accounts with banks. 
Journal of Poverty, Investment and Development

ISSNxxxx-xxxx (Paper) ISSN xxxx-xxxx (Online)

Vol.1, Issue No.1, pp 54 - 73, 2016

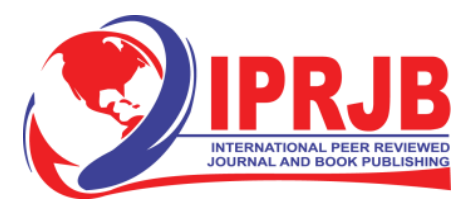

www.iprjb.org

Factors affecting financial inclusion included gender, level of education and distance from Collective Investment Scheme. The findings imply that females have a significantly higher financial inclusion compared to males. Females are 0.928 times more likely to participate in collective investment schemes compared to males and this demonstrates that CIS have impacted positively on financial inclusion as a far as women respondents are concerned. The findings are inconsistent with those in Small Change Partnership (2006) which asserted that households headed by a woman, including lone parents, single pensioners, widows and separated women have lower financial inclusion. The findings also disagree with those in Financial Sector Inclusion Survey (2010) which asserted that in 2006, $13.3 \%$ of women compared to $22.6 \%$ of men used a bank account and being a woman was associated with a significantly lower likelihood of bank access. The inconsistency of the results may be explained by the nature and composition of CIS and also the risk averseness attributed to women investors. Given a choice between a balanced fund of A CIs and the direct investment in Equity/Stock market, women investors would probably prefer CIS to direct stock market investment primarily due to the risk involved. The findings agree with those in Fletschner et al., 2010; who noted that women are more risk averse investors and would prefer investing in CIS since CIS offers a balanced fund, money market funds and bond funds which are less risky. The findings also agree with those in Croson and Gneezy (2008) and those Browne (2008) which reveal that whether a result of innate psychological characteristics or of attitudes influenced by social conditions, men and women tend to exhibit systematic differences in their behavior. Of particular importance when assessing the adequacy of financial products available to rural women is how men and women differ in their willingness to take risks. Studies in psychology and economics found that, on average, women tend to be more averse to risk than men and that, other things equal, women are more likely to forego activities that offer higher returns if these opportunities require them to bear too much risk (Fletschner et al., 2010; Croson and Gneezy, 2008, and; Browne, 2006).

Study findings in table 4.4 revealed that there is a positive but insignificant relationship between age and financial inclusion. This was evidenced by a regression coefficient of 0.308 . The associated $\mathrm{p}$ value (sig) was 0.434 . The findings imply that an increase in age by one unit increases financial inclusion by 0.308 units. However, the insignificant $\mathrm{p}$ values indicate that older respondents do not have a significantly higher financial inclusion compared to younger respondents. This has the implication that financial inclusion is the same in younger and older respondents and that CIS has brought about financial inclusion among respondents of different ages.

Findings in table 4.4 revealed that there is a positive and significant relationship between the level of education and financial inclusion. This was evidenced by a regression coefficient of 0.683 . The associated $\mathrm{p}$ value ( $\mathrm{sig}$ ) was 0.015 . The findings imply that an increase in level of education by one unit increases financial inclusion by 0.683 units. Therefore, highly educated respondents have a significantly higher financial inclusion compared to less educated respondents. This implies that CIS have not ensured equal access to financial opportunities to both educated and uneducated respondents. The findings compare well with Financial Sector Inclusion Survey (2010) with education was also strongly associated with the likelihood of bank use in 2006. The findings also agree with those in Rachana (2011) who asserted that there is significance impact of the rural public's education on the having the bank account. 
Results in table 4.4 revealed that there is a positive but insignificant relationship between the level of income and financial inclusion. This was evidenced by a regression coefficient of 0.503 . The associated $\mathrm{p}$ value (sig) was 0.163 . The findings imply that an increase in level of income by one unit increases financial inclusion by 0.503 units. However, the insignificant $p$ values indicate that high income respondents do not have a significantly higher financial inclusion compared to lower income respondents. This further implies that CIS have brought about financial inclusion among respondents of different income status. The findings disagree with those in Worldbank (2008) and Beck, Demirguc-Kunt and Martinez Peria (2007b) who asserted that high minimum balances to open and maintain bank accounts and high annual fees can constitute high access barriers to finance for large population in the developing world. The findings also disagree to those in Finaccess (2009), which found out that income is one of the strongest predictors of usage of both formal and informal financial services. Higher income earners have higher use of formal and informal financial services than lower income earners. The study findings also disagree to those in Wainaina (2009) who concluded that in Kenya, lack of access to financial services is more widespread amongst lower income and rural households and small-scale enterprises.

Result in table 4.4 indicates that there is a negative and insignificant relationship between the distance from CIS and financial inclusion. This was evidenced by a regression coefficient of 0.138 . The associated $\mathrm{p}$ value ( $\mathrm{sig}$ ) was 0.098 (note; insignificant at 0.05 level but significant at 0.1). The findings imply that an increase in the distance from collective scheme one unit decreases financial inclusion by 0.138 units. Therefore, respondents who are far from the collective investment schemes have a significantly lower financial inclusion compared to respondents whose work place is near the collective investment schemes. The findings imply that CIS have not brought about financial inclusion as far as distance is concerned. For financial inclusion, both the respondents who are far from CIS and those who are near should have almost the same level of financial inclusion. The findings also compare to those in Finaccess (2009) which asserted that rural Kenyans are less likely to use formal and other informal financial services than urban Kenyans.

\subsection{DISCUSSION CONCLUSIONS AND RECOMMENDATIONS}

\subsection{Discussion}

The general objective of this study was to determine the impact of collective investment schemes in financial inclusion in Kenya. A sample size of a total population of ninety eight (96) respondents was drawn from all the 11 collective investment schemes in Kenya. For purposes of collecting primary data, the researcher developed and administered a questionnaire and the results obtained were analyzed using Microsoft Excel and Statistical Package for Social Sciences (SPSS

Findings revealed that there is a positive and significant relationship between the level of education and financial inclusion. This was evidenced by a regression coefficient of 0.683 . The associated $\mathrm{p}$ value ( $\mathrm{sig}$ ) was 0.015 . The findings imply that an increase in level of education by 
one unit increases financial inclusion by 0.936 units. Therefore, highly educated respondents have a significantly higher financial inclusion compared to less educated respondents.

Result indicates that there is a negative and insignificant relationship between the distance from CIS and financial inclusion. This was evidenced by a regression coefficient of -0.138 . The associated $\mathrm{p}$ value ( $\mathrm{sig}$ ) was 0.098. The findings imply that an increase in the distance from collective scheme one unit decreases financial inclusion by 0.138 units. Therefore, respondents who are far from the collective investment schemes have a higher financial inclusion compared to respondents whose work place is near the collective investment schemes. However, the difference in financial inclusion between respondents who are far from CIS and those who are near is insignificant.

Following the study findings it was possible to conclude that collective investment schemes have not succeeded in increasing financial inclusion. This conclusion was arrived at since the majority of respondents reported low scores on measurers of financial inclusion.

It was also possible to conclude that those respondents who were well educated had a higher level of financial inclusion primarily because they had higher chances of learning about collective investment schemes and the investment options. It was also possible to conclude that age too influenced investments in collective investment schemes though the influence was insignificant.

The study also concludes that gender and level of income also influence the investment in the collective schemes with those with higher income earning investing more than those earning little amounts. Furthermore, men are more likely to invest in collective investment schemes than women either due to the risk involved or the inability of women to engage in such opportunities.

Distance from CIS schemes also influenced financial inclusion through not significantly. Still a lot more need to be done since overall financial inclusion among all respondents irrespective of distance was low.

\section{Recommendations}

Following the study conclusions, it is recommended that the collective investment firms need to focus their marketing drive on several areas. First and foremost, collective investment schemes need to continue enhancing access to women but also not forget to encourage men to invest in CIS.

The drive towards encouraging men will ensure that they enhance proper gender inclusion in the collective investment schemes. They may also tailor make products to suit women. For instance, they could ensure that women who join collective schemes are given free pedicure treats and have the options of joining collective schemes in Chama's.

Collective schemes also need to enhance financial inclusion as far as the level of education is concerned. They need to hold awareness campaigns targeting the less educated so that they can include them in the collective investment schemes clientele base. Meanwhile, the government also has a role to play in enhancing the education of the clientele by sponsoring free education and instituting policies aimed at enhancing adults' education. 
The collective investment schemes can enhance financial inclusion by targeting their marketing campaigns at low income earners. This will increase awareness that there are products that cater for low income earners. In addition, the government may institute policies aimed at boosting the income potential of the low income earners.

Collective investment schemes needs to also target market Kenyans whose work place is far from the Central Business District. Since a majority of the collective investment schemes are located at the CBD, then it may be important to organize for road shows and promotions aimed at customers located far from the CBD.

\subsection{Areas of further study}

Further studies need to be conducted on the factors that affect the achievement of the goals, objectives and strategies. This may shed light on the reasons why the collective investment schemes have not achieved their objectives of financial inclusion. In addition, a study on the critical success factors (CSF) for the collective investment schemes sector may also be necessary so that the management may have insights on what to concentrate on. That is, such a study would help to identify the critical few out of the trivial many

\section{References}

Abiad, A, and Mody, A. (2003), "Financial Reform: What Shakes It? What Shapes It?," IMF Working Paper 03/70 (Washington: International Monetary Fund); forthcoming, American Economic Review.

Abiad, A, Oomes,N. and Ueda K ( 2004). The Quality Effect: Does Financial Liberalization Improve the Allocation of Capital? International Monetary Fund WP/04/112

Arestis, P., Dennelnades, and Luintel, K. (2001) Financial Development and Economic Growth: The Role of Stock Markets, Journal of Money, Credit and Banking, 33 (i): 16-41 in Olofin, S.O and Afangideh, U.J. Financial Structure and Economic Growth in Nigeria. A macroeconomic Approach.

Bagehot, W. [1873] Lombard Street. Homewood, Il: Richard D. Irwin, 1962 Edition.

Bihari, S. c. (2011). Growth through financial inclusion in India. Journal of International Business Ethics Vol.4 No.1.

Blake A.W. (2008). The Value Chain of a Collective Investment Scheme and the Impact thereof on the Individual Investor.University of South Africa

Buti,S. (2007). "Asset Choice Regulation in Mutual Funds" EFA Maastricht Meetings Paper No 3516 available at http://papers.ssrn.com/sol3/results last accessed on 27th september 2007 p.3.Capital Markets Authority Handbook 
Chakrabarty K.C. (2011), Financial Inclusion. Seminar on "Financial Inclusion: Partnership between Banks, MFIs and Communities", New Delhi, 14 October 2011.

Chandran, E. (2004). Research Methods: A Quantitative Approach with Illustrations from Christian Ministries. Nairobi: Daystar University.

Chattopadhyay, S. K. (2011), "Financial Inclusion in India: A case-study of West Bengal". W P $\mathrm{S}$ (DEPR): 8 / 2011. rbi working paper series. department of economic and policy research

Citizens Advice, 2006, Out of Pocket - CAB evidence on the impact of fee-charging cash machines, July 2006

Cooper, D.R and Schindler, P.S (2006). “Business Research Methods", 9 , edition. McGrawHill Publishing, Co. Ltd. New Delhi-India

Cooper, D.R and Schindler, P.S (2011). "Business Research Methods", $11^{\text {th }}$, edition. McGrawHill Publishing, Co. Ltd. New Delhi-India.

Cronbach, L. J. 1951. Coefficient alpha and the internal structure of tests. Psychometrika 16:297-334.

Finaccess(2009). Financial Inclusion In Kenya. Project Implementation Unit, Financial and Legal Sector Technical Assistance Project, Office of The Deputy Prime Minister and Ministry of Finance.

Financial Sector Inclusion Survey (2010). Financial Inclusion in Kenya. Survey Results and analysis from finaccess2009. ISBN Number: 978-9966-019-00-4

G.O.K (2000). Capital Markets Authority (Amendment) Act, Government Press: Nairobi

Galindo, Arturo, Fabio Schiantarelli, and Andrew Weiss, 2002, "Does Financial Liberalization Improve the Allocation of Investment?: Micro Evidence From Developing Countries," IADB Research Department Working Paper No. 467 (Washington: Inter-American Development Bank).

Hicks, J (1969). A Theory of Economic History. Oxford: Clarendon Press.

Ibrahim M.M. (2005), Performance Evaluation of the Mutual Fund industry inNigeria: 1990-2002

Israel, Glen D. (2009). Determining_sample size. Gainesville, FL: Florida State University, Cooperative Extension Service. Retrieved 7 April, 2012 from http://edis.ifas.ufl.edu/pd006 (Archived by WebCite at http://www.webcitation.org/66kKEIC0b) 
Kagunga P. K. (2010). A Comparison of Performance between unit trusts and a market portfolio of shares at Nairobi stock Exchange. Unpublished MBA Research Project, University of Nairobi

Karen E., Alberto L. and Rud J. (2010). Financial inclusion, household investment and growth in Kenya and Tanzania. Project Briefing. No 43.

Kempson E,. Whyley C.,1999, Kept out or opted out? Understanding and Combating Financial Exclusion, ThePolicyPress. http://www.pfrc.bris.ac.uk/Reports/Kept_out_opted_out.pdf

Kempson E. and Whyley C., 2000, Banks and Micro Lending: Support, Cooperation and Learning, University of Bristol Personal Finance Research Centre in co-operation with the institute for Financial Services.

Kempson. E., Atkinson. A. and Pilley. O., 2004, Policy Level Response to Financial Exclusion in Developed Economies: Lessons for Developing Economies, The Personal Finance Research Centre prepared for the Department of International Development.

Kenya Vision 2030 (2007)

Kogi W. (2003). The Future of Collective Investment Schemes in the Kenya Capital Market. Unpublished MBA Research Project, University of Nairobi

Kothari C.R. (2004). Quantitative Techniques. New Delhi New Age International publishers.

Lamuno . G.F. (2009). Collective Investment Schemes In Emerging Markets: An Assessment Of The Regulatory Framework For Investor Protection In Uganda. Master Thesis. Makerere University

Levine, R. (2002) Bank-based or Market-based Financial Systems: which is Better? Journal of Financial International 11 (4): 398-428

Leyshon, A. and Thrift, N. 1995: Geographies of financial exclusion: financial abandonment in Britain and the United States. Transactions, Institute of British Geographers NS 20, 31241.

Maiyo J. E. (2007). The Performance of Unit Trust in Kenya. Unpublished MBA Research Project, University of Nairobi

Mehrotra,N, V.Puhazhendhi, G.G.Nair, and B.B.Sahoo (2009), "Financial Inclusion - An Overview", NABARD Occasional Paper No. 48 
Mugenda, Olive M. and Mugenda, Abel G. (2003). Research Methods: Quantitative and Qualitative Approaches, Acts Press, Nairobi-Kenya

Nzotta, S. M. (2004) Money, Banking and Finance, Theory and Practice Owerri. Hudson Jude Publishers.

Olofin, S. and Afangideh, Udoma J. (2008) Financial Structure and Economic Growth in Nigeria, Nigerian Journal of Securities and Finance Vol. 13 No. 1 Pp 47-68

Popiel, P.A. (1990) Developing Financial Markets International Finance Corporation, Washington.

Rachana, T. (2011). Financial Inclusion and Performance of Rural Co operative Banks in Gujarat. Research Journal of Finance and Accounting www.iiste.org ISSN 2222-1697 (Paper) ISSN 2222-2847 (Online) Vol 2, No 6, 2011

Robinson J (1952), The Generalization of the General Theory, the Rate of Interest and Other Essays, MacMillan, London, UK.

Schumpeter, J (1912). The Theory of Economic Development. Leipzig: Dunker \& Humblot, translated by R Opie. Cambridge, MA: Harvard U. Press, 1934.

Security and Exchange Commission of Ghana (2010), "What are Collective InvestmentSchemes", Available onwww.secghana.org/investor/cischemes.asp

Sinclair,S., McHardy, F., Dobbie,L., Lindsay,K., and Gillespie M.(2011). Understanding financial inclusion. Magenta Publishing Ltd. Uk.

Small Change Partnership, 2006, Financial Exclusion Baseline and Mapping, South East Economic Development Agency (SEEDA). http : // www . seeda.co.uk/publications /social_inclusion / docs / SCRP-Demand Report.pdf

Swamy, V. and Vijayalakshmi (2011). Role of Financial Inclusion for Inclusive Growth in India. Issues \& Challenges.

The Treasury Select Committee, 2006, Banking, the Unbanked, Banking Service, the Post Office Account Card and Financial Inclusion, London.

Thompson, J.(2004) “Governance Of Collective Investment Schemes (CIS)”(Discussion Draft For Comment, Directorate For Financial And Enterprise Affairs July available at www.oecd.org/dataoecd/13/31/33621909.pdf accessed o 14th September 2007 p.5.

Townsend, Robert M, and Kenichi Ueda, (2003), "Financial Inclusion, Inequality, and Growth: A Model-Based Quantitative Evaluation," IMF Working Paper 03/193 (Washington: International Monetary Fund). 
World Bank (2006b). The Role of Postal Networks in Expanding Access to Financial Services. Washington, DC.

World Bank (2007), 'Finance for All:Policy and Pitfalls in Expanding Access”, Policy Research Report, http//go World Bank.org/

World Bank(2008).finance for all? policies and pitfalls in expanding access. The International Bank for Reconstruction and Development / The World Bank

Nairobi securities Exchange (NSE) (2010). History of Organisation Our Brief History http://www.nse.co.ke/about-nse/history-of-organisation.html

Fletschner, D., C.L. Anderson and A. Cullen. (2010). Are women as likely to take risks and compete? Behavioral findings from central Vietnam. Journal of Development Studies (forthcoming).

Browne, K. (2006). Evolved sex differences and occupational segregation. Journal of Organizational Behavior, Vol. 27:143-162.

Croson, R. and Gneezy U. (2008). Gender differences in preferences. Journal of Economic Literature, Vol. 47(2): 448-474. 